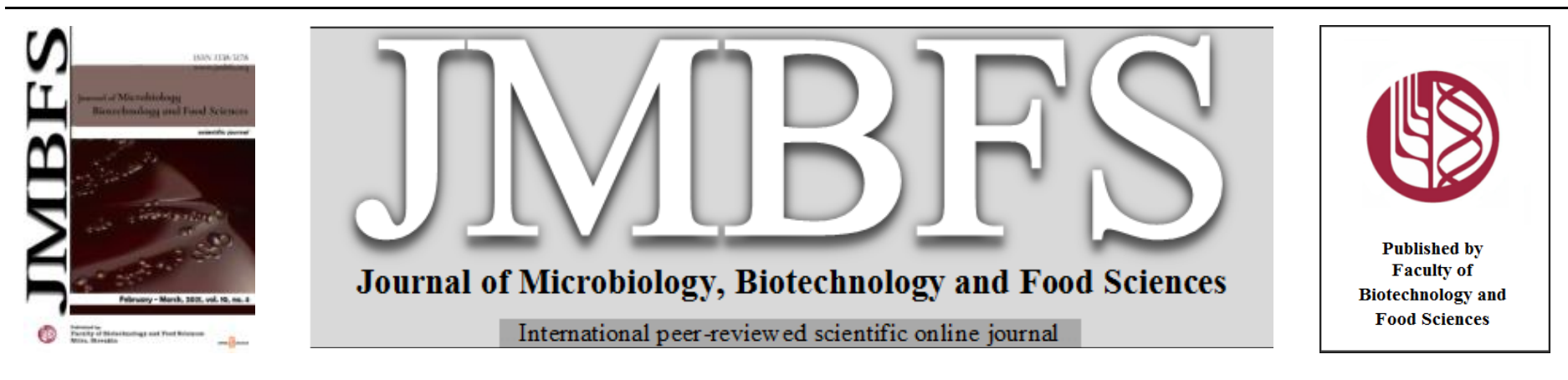

\title{
UTILIZATION OF MICROWAVE ASSISTED BLACK CUMIN SEED EXTRACT AS HYPOCHOLESTEROLEMIC AGENT IN ALBINO RATS
}

\author{
Anees Ahmed Khalil ${ }^{1}$, Ahood Khalid ${ }^{\prime}$, Hira Khalid ${ }^{2}$, Ayesha Aslam ${ }^{l}$, Quratul Ain Shahid ${ }^{1}$, Miroslava Hlebová ${ }^{3}$, Maksim Rebezov $^{4,5,6}$ \\ Marina Derkho ${ }^{7}$, Mohammad Ali Shariati $*^{8,9}$
}

Address(es):

${ }^{1}$ University of Lahore, Faculty of Allied Health Sciences, University Institute of Diet and Nutritional Sciences, 1-km Defense road, near Bhuptian chowk, Lahore, Punjab, Phone no. (042)111-865-865

${ }^{2}$ Sharif Medical and Dental College, Raiwind Road, Jati Umra, Lahore, Punjab, Phone no. (042)111-123-786

${ }^{3}$ University of SS. Cyril and Methodius, Department of Biology, Faculty of Natural Sciences, Nám. J. Herdu 2, SK-91701 Trnava, Slovak Republic.

${ }^{4}$ V. M. Gorbatov Federal Research Center for Food Systems of Russian Academy of Sciences, Moscow, Russian Federation

${ }^{5}$ Prokhorov General Physics Institute, Russian Academy of Sciences, Moscow, Russian Federation

${ }^{6}$ Russian state agrarian correspondence university, Balashikha, Russian Federation

${ }^{7}$ South-Ural State Agrarian University, Troitsk, Russian Federation

${ }^{8}$ K.G. Razumovsky Moscow State University of Technologies and Management (the First Cossack University), Moscow, Russian Federation

${ }^{9}$ Food Engineering Department, Shakarim State University of Semey, Semey, Kazakhstan

*Corresponding author: ahoodkhalid@hotmail.com ; m.ali.sh@semgu.kz

doi: 10.15414/jmbfs.2021.10.4.536-540

ARTICLE INFO

Received 6. 7. 2020

Revised 4. 10. 2020

Accepted 6. 10. 2020

Published 1.2. 2021

Regular article

open $\partial$ ACCESS

\begin{abstract}
Main aim of this study was to evaluate hypocholesterolemic potential of microwave-assisted black cumin (Nigella sativa) extracts (MABCEs) in a rat bioassay. Efficacy trial in this study comprised of 25 male albino rats which were divided into 5 groups having 5 rats each. Out of these 25 rats, 20 were hypercholesterolemic and 5 were normal rats. Hypercholesterolemia was induced by providing high cholesterol diet for 15 days, and after the onset of hypercholesterolemia these rats were administered with different concentrations of the MABCE i.e. $150,300 \& 450 \mathrm{mg} / \mathrm{kg}$ B.W. for a period of 28 days. The administration of extract displayed significant lowering in the lipid profile of the experimental rats. The $300 \mathrm{mg} / \mathrm{kg}$ B.W. dose of black cumin MAE provided the optimum results giving cholesterol, triglyceride and LDL-c content lowered by $14.9 \%, 11.32 \%$ and $12 \%$ and value of HDL-c elevated by $12.88 \%$ compared to the hypercholesterolemic control. Similarly, there was a percent elevation in levels of SOD and CAT by $19.83 \%$ and $13.97 \%$. The current study concluded that MABCEs have hypocholesterolemic effect thus can be used for its therapeutic property.
\end{abstract}

Keywords: Microwave assisted extraction, phenolics, hypercholesterolemia, antioxidant, black cumin

\section{INTRODUCTION}

Nutraceuticals have been known throughout the world and are found to be well credited for their use as therapeutic agents. The properties these nutraceuticals possess have great effect inside the body and assists with the structural and functional maintenance also preventing from acquiring various diseases (Espin et al., 2007). There are a number of plants and seed which provide with the different phytochemicals including polyphenols, flavonoids, anthocyanins etc. that we consume on our daily basis (Bech-Larsen and Scholderer, 2007). Different diseases are being treated in current age by the help of these nutraceuticals that are present in the plants consumed in our diet. Such diet-based therapies are the need of the hour as the drug load is increasing by the use of multiple medicines for different disorders (Espin et al., 2007; Bech-Larsen and Scholderer, 2007).

Black cumin also commonly known as Kalonji in Urdu whereas its scientific name is Nigella sativa is a vital plant especially the seeds as they have the medicinal history for treating different diseases and is known to be a considerable part of the family named Ranunculacaea (Aggarwal and Kunnumakkara, 2009). The plant of black cumin seed has acquired a notable place because of its use as a medicine. Study shows that this seed has been in use since a long time traditionally by consuming the seed and in its extract form as well (Ramadan and Morsel, 2003). It provides with the treatment of different autoimmune diseases also in earlier days it was used for treating headaches, fever, stroke, heart related diseases. It was shown to have reduced the effect of inflammation thus promoting anti-inflammatory property of the seed (Cheikh-Rouhou et al., 2007).

The disturbance in the lipid concentrations in the human body may lead to hyperlipidaemia or hypolipidemia (Bamosa et al., 2002). An increase in the level of lipids including cholesterol, LDL and triglycerides is the cause of hyperlipidaemia and the incidence of this abnormality has increased hugely in the past years. The common condition that is found in our society is the hypercholesterolemia which is contributes to the development of ischemic heart disease (Ramadan and Morsel, 2003). The World Health Organization (WHO) has reported that the ischemic heart disease has been the major cause of deaths in Pakistan in 2012 that killed around 111.4 thousand individuals (WHO, 2019). The need to cure and prevent this disease from increasing by the hour is very important thus we require therapeutic agents that will do the job. Black cumin seed in earlier studies reported to have hypercholesterolemic properties and was able to prevent from such condition (Khalid et al., 2019).

There are many different procedures used in order to extract the phenolics present in a plant material. Some of the earlier conventional procedures included maceration, decoction and distillation, respectively. However, in this modern age the use of non-conventional procedures is increasing day by day. Some of these procedures include the ultra-sound assisted extraction (UAE), microwave assisted extraction (MAE), pulse-electric field extraction (PEF) and so on. These nonconventional techniques provide a number of benefits as compared to the conventional techniques. Microwave assisted extraction (MAE), one of the nonconventional technique for the extraction of oils and extracts from plants is being used greatly these days. The method specifically involves the microwave radiations which assists the extraction. This technique has been reported as one of the better techniques as it provides with an increased yield of extract, far efficient extraction, reduced use of the solvent and lesser time to achieve the extraction (Liu et al., 2013). Likewise, in our study the phenolics are extracted through the microwave assisted extraction technique from the seed of our interest i.e. black cumin seed.

The aim of this study was to extract the essential oils from the seed of black cumin by the method of microwave assisted extraction and then administrating 
the extract with higher phenolics to the experimental rats in order to determine the hypercholesterolemic effect of the extract obtained

\section{MATERIAL AND METHODS}

\section{Plant Material}

Black cumin seeds (Nigella sativa) were procured from a local market in Lahore. The seeds of black were washed, and then air-dried at room temperature to avoid any dirt particles or other impurities. The seeds after drying were crushed in an electric grinder for $1 \mathrm{~min}$ until a fine powder was obtained to further proceed with the experiments.

\section{Preparation of extract}

The extraction was performed in an adapted commercial kitchen microwave oven whose maximum output was $700 \mathrm{~W}$ with $2450 \mathrm{MHz}$ of microwave irradiation frequency and a power divider of three levels (low, medium, high). In the MAE procedure, a $25 \mathrm{~g}$ aliquot of ground black cumin seeds were placed in a $250 \mathrm{ml}$ round bottom flask; $25 \mathrm{ml}$ of distilled water was then added to moisturize the seeds for around $30 \mathrm{~min}$. The flask was then connected to a Clevenger apparatus and heated using varied level powers of 50,100 and $150 \mathrm{~W}$ for extraction time 1 , 5,10 and 15 minutes respectively. The volatile distillate was eluted out by $\mathrm{n}$ hexane and dried through anhydrous sodium sulphate. The n-hexane was removed later under vacuum conditions and the extract was refrigerated prior to analysis (Liu et al., 2013).

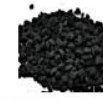

Nigella sativa seeds
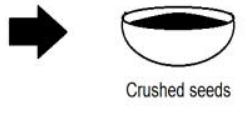

\section{Day 1: Administration of MAE of black cumin along with high cholesterol die}

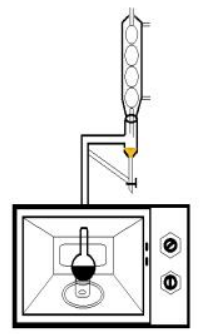

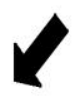
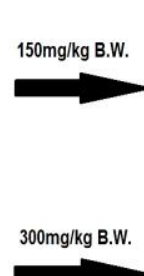

the sample

sample
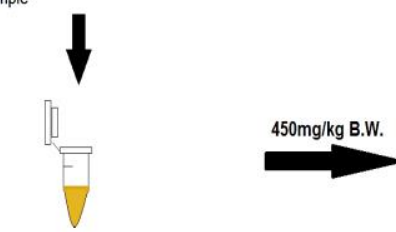

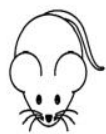

Day 14: Administration of MAE of black cumin along with high cholesterol diet (increase in weight observed)
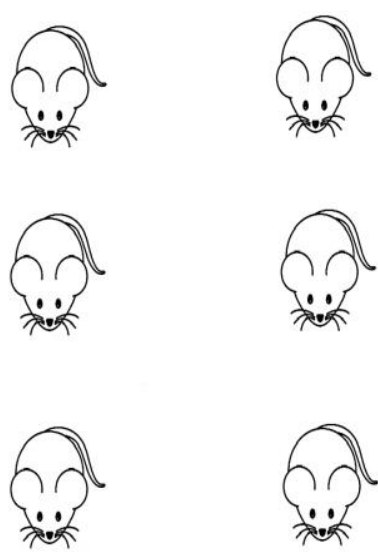

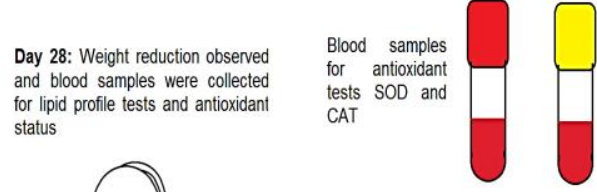

Blood samples for lipid profile tests TC, TG LDL and HDL

Figure 1 Graphical representation of experimental design. Microwave assisted extraction of Nigella sativa seeds and administration of extracts in different doses to the study rats. After the administration analysis of the blood samples to determine the lipid lowering effect of MAE of black cumin seeds

\section{Experimental animals}

Male albino rats were purchased from animal house of Institute of Molecular Biology and Biotechnology (IMBB), The University of Lahore, specifically weighing $200 \mathrm{~g}-250 \mathrm{~g}$. The rats were then acclimatized on a basal diet for oneweek time period. The environmental conditions were controlled through the tria period i.e. temperature $\left(23 \pm 2{ }^{\circ} \mathrm{C}\right)$ and relative humidity $(55 \pm 5 \%)$ along with 12- h light-dark period (Makni et al., 2008).

\section{Induction of Hypercholesterolemia}

Experimental hypercholesterolemic diet was designed using corn oil (10\%), corn starch $(64.5 \%)$, cholesterol $(1.5 \%)$, protein $(10 \%)$, cellulose $(10 \%)$, mineral $(3 \%)$ and vitamins $(1 \%)$. Groups $\mathrm{B}_{0}, \mathrm{~B}_{1}, \mathrm{~B}_{2}, \& \mathrm{~B}_{3}$ were subjected to high cholesterol diet for first 15 days for the purpose of inducing hypercholesterolemia. The induction was validated by examining their total cholesterol content at $15^{\text {th }}$ day (Imran et al., 2018).

\section{Experimental design}

The 25 rats in our study were divided into 5 groups i.e. $\mathrm{N}_{0}, \mathrm{~B}_{0}, \mathrm{~B}_{1}, \mathrm{~B}_{2}$, and $\mathrm{B}_{3}$ Group $\mathrm{N}_{0}$, the normal group was subjected to normal basal diet throughout the study, while group $\mathrm{B}_{0}$ (hypercholesterolemic control group) was subjected to the hypercholesterolemic diet only without the administration of any extract. On the other hand, remaining groups i.e. $\mathrm{B}_{1}, \mathrm{~B}_{2}, \mathrm{~B}_{3}$ were fed on high cholesterol diet along with various concentrations $(150,300$ and $450 \mathrm{mg} / \mathrm{kg} \mathrm{B.W.)} \mathrm{of} \mathrm{black}$ cumin seed extract (Khazdair, 2018).

\section{Effect of extract on hypercholesterolemia and safety assessment}

Rats were anesthetized by exposure to isoflurane/chloroform and the blood samples was collected in tubes by cardiac puncture and examined at 0 day (baseline trend), $15^{\text {th }}$ day (post administration of cholesterol rich diet) and $21^{\text {st }}$ day post induction of hypercholesterolemia along with administration of respective extracts to authenticate hypercholesterolemic effect of the extracts (Imran et al., 2018).

Statistical analysis
Collected data was reported as mean value \pm standard deviation. Completely randomized design was conducted with ANOVA at a significance level of $p \leq 0.05$. The significant difference between mean values was determined by Tukey-HSD comparison test. Statistical analysis was determined by using Statistical package (Statistix 9.0) (Steel et al., 1997).

\section{RESULTS}

\section{Total cholesterol}

Statistical analysis revealed that treatments and time interval $(0,14,28$ days $)$ have significant $(P \leq 0.05)$ effect on cholesterol content of experimental rats. The mean values regarding the effect of different administrated concentrations (150, $300 \& 450 \mathrm{mg} / \mathrm{kg} \mathrm{B.W.)} \mathrm{of} \mathrm{MABCEs} \mathrm{on} \mathrm{the} \mathrm{cholesterol} \mathrm{content} \mathrm{of} \mathrm{experimenta}$ rats are mentioned in Figure 2. Results for total cholesterol content showed maximum $(29.4 \%)$ percent reduction in group $B_{2}$ followed by $B_{1}(23.5 \%)$ and $B_{3}$ $(22.40 \%)$. As compared to Bo $(232.65+3.22 \mathrm{mg} / \mathrm{dL})$, cholesterol content observed in groups $B_{1}, \quad B_{2}, \quad$ and $B_{3}$ were as $177.79 \pm 2.50 \mathrm{mg} / \mathrm{dL}$, $164.21 \pm 3.57 \mathrm{mg} / \mathrm{dL}, \quad \& 180.52 \pm 2.80 \mathrm{mg} / \mathrm{dL}$, respectively on $28^{\text {th }}$ day of administration of MABCE. The highest reduction in the cholesterol content was observed in $\mathrm{B}_{2}$ hypercholesterolemic group. 


\section{total cholesterol}

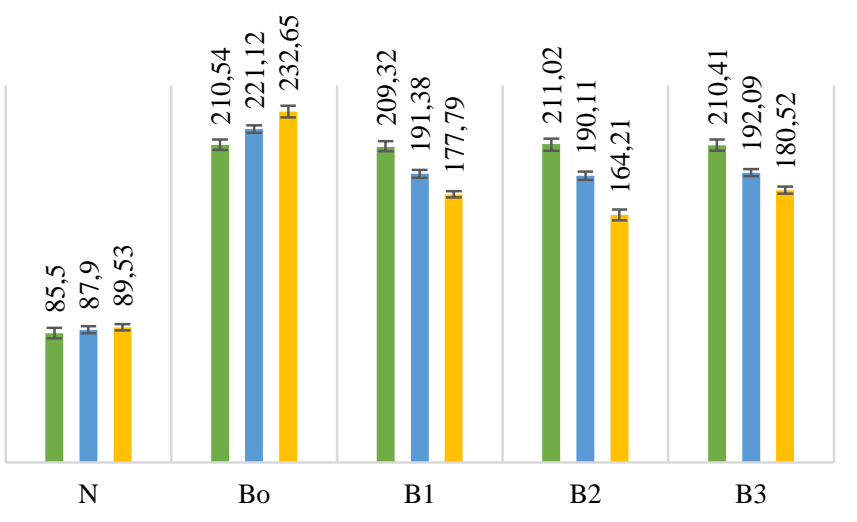

\section{Total Triglycerides}

Statistical analysis revealed that treatments and time interval have significan $(p \leq 0.05)$ effect on total triglyceride concentration in experimental rats. The mean values for the concentration of triglycerides in rats are presented in Table 1. Total triglyceride content noticed in $B_{o}(168.67 \pm 2.80 \mathrm{mg} / \mathrm{dL})$ reduced to $151.22+2.98 \mathrm{mg} / \mathrm{dL}, 149.57+3.55 \mathrm{mg} / \mathrm{dL}$, and $152.03+2.65 \mathrm{mg} / \mathrm{dL}$ in groups $\mathrm{B}_{1}$, $\mathrm{B}_{2}, \mathrm{~B}_{3}$, respectively. On the other hand, total triglycerides content decreased from $161.10 \pm 2.49 \mathrm{mg} / \mathrm{dL} \quad\left(0\right.$ day) to $155.10 \pm 2.65 \mathrm{mg} / \mathrm{dL} \quad\left(14^{\text {th }}\right.$ day) and $149.92+3.17 \mathrm{mg} / \mathrm{dL} \quad\left(28^{\text {th }}\right.$ day), respectively. As compared to hypercholesterolemic control group $\left(\mathrm{B}_{\mathrm{o}}\right)$, significant percent reduction of $10.34 \%$, $11.32 \%$ and $9.87 \%$ was observed in hypercholesterolemic rats that were administrated to $150 \mathrm{mg} / \mathrm{kg}\left(\mathrm{B}_{1}\right), 300 \mathrm{mg} / \mathrm{kg}\left(\mathrm{B}_{2}\right), 450 \mathrm{mg} / \mathrm{kg}\left(\mathrm{B}_{3}\right)$ of microwave assisted black cumin seed extracts. The group $\mathrm{B}_{2}$ showed the maximum percent reduction.

Figure 2 Effect of MAE of Nigella sativa (black cumin) on total cholesterol levels in hypercholesterolemic rats

$\mathrm{N}_{\mathrm{o}}=$ Basal diet; $\mathrm{B}_{0}=\mathrm{HCD} ; \mathrm{B}_{1}=\mathrm{HCD}+\operatorname{MABCE}(150 \mathrm{mg} / \mathrm{kg} \mathrm{B} . \mathrm{W}.) ; \mathrm{B}_{2}=\mathrm{HCD}+$ MABCE (300mg/kg B.W.); B $_{3}=$ HCD + MABCE (450mg/kg B.W.)

Table 1 Effect of MAE of Nigella sativa (black cumin) on triglyceride levels in hypercholesterolemic rats

\begin{tabular}{|c|c|c|c|c|c|}
\hline \multirow[b]{2}{*}{ Parameter } & \multirow[b]{2}{*}{ Treatments } & \multicolumn{3}{|c|}{ Study intervals (days) } & \multirow[t]{2}{*}{ Means } \\
\hline & & 0 & 14 & 28 & \\
\hline \multirow{5}{*}{$\begin{array}{l}\text { Triglycerides - } \\
\text { mg/dL }\end{array}$} & $\mathrm{N}_{\mathrm{o}}$ & $76.12 \pm 1.09$ & $77.59 \pm 2.33$ & $80.42 \pm 2.17$ & $78.04 \pm 1.86$ \\
\hline & $\mathrm{B}_{\mathrm{o}}$ & $160.3 \overline{6} \pm 2.75$ & $169.23 \pm 1.77$ & $176.41 \pm 3.89$ & $168.67 \pm 2.80^{\mathrm{a}}$ \\
\hline & $\mathrm{B}_{1}$ & $161.53 \pm 3.54$ & $150.60 \pm 2.67$ & $141.54 \pm 2.74$ & $151.22 \pm 2.98^{\mathrm{b}}$ \\
\hline & $\mathrm{B}_{2}$ & $160.50 \pm 2.69$ & $149.45 \pm 3.69$ & $138.76 \pm 4.28$ & $149.57 \pm 3.55^{\mathrm{b}}$ \\
\hline & $\mathrm{B}_{3}$ & $162.01 \pm 2.36$ & $151.11 \pm 2.81$ & $142.98 \pm 2.79$ & $152.03 \pm 2.65^{\mathrm{b}}$ \\
\hline Means & & $161.10 \pm 2.49^{\mathrm{a}}$ & $155.10 \pm 2.65^{\mathrm{b}}$ & $149.92+3.17^{\mathrm{c}}$ & \\
\hline
\end{tabular}

LDL

The results of the statistical analysis demonstrated significant $(p \leq 0.05)$ effect of variables (treatments and time intervals) on the LDL content of the experimental rats. The mean values for the LDL content are presented in Table 2. The results evaluated the effect of microwave assisted black cumin extracts on hypercholesterolemic rats. The LDL concentration lowered from
$133.13+2.65 \mathrm{mg} / \mathrm{dL}$ at 0 day to $128.92+2.98 \mathrm{mg} / \mathrm{dL}$ at $14^{\text {th }}$ day and $124.99 \pm 1.94 \mathrm{mg} / \mathrm{dL}$ at $28^{\text {th }}$ day, respectively. However, the $\mathrm{LDL}$ content displayed in $\mathrm{B}_{\mathrm{o}}(138.56 \pm 2.53 \mathrm{mg} / \mathrm{dL})$ was lowered to $128.08 \pm 2.94 \mathrm{mg} / \mathrm{dL}\left(\mathrm{B}_{1}\right)$ $121.67+2.63 \mathrm{mg} / \mathrm{dL}\left(\mathrm{B}_{2}\right)$ and $127.74+2.55 \mathrm{mg} / \mathrm{dL}\left(\mathrm{B}_{3}\right)$, respectively. In comparison to the hypercholesterolemic control group $\mathrm{B}_{\mathrm{o}}$, considerable percent reduction was observed in $\mathrm{B}_{1}(7.5 \%), \mathrm{B}_{2}(12 \%)$ and $\mathrm{B}_{3}(7.8 \%)$, respectively.

Table 2 Effect of MAE of Nigella sativa (black cumin) on LDL levels in hypercholesterolemic rats

\begin{tabular}{|c|c|c|c|c|c|}
\hline \multirow{2}{*}{ Parameter } & \multirow{2}{*}{ Treatments } & \multicolumn{3}{|c|}{ Study intervals (days) } & \multirow[t]{2}{*}{ Means } \\
\hline & & 0 & 14 & 28 & \\
\hline & $\mathrm{N}_{\mathrm{o}}$ & $49.52 \pm 1.97$ & $50.44 \pm 2.14$ & $47.13 \pm 1.77$ & $49.03 \pm 1.96$ \\
\hline LDL cholesterol & $\mathrm{B}_{\mathrm{o}}$ & $132.42+3.21$ & $138.92 \pm 2.34$ & $144.3 \overline{4} \pm 2.05$ & $138.56 \pm 2.53^{\mathrm{a}}$ \\
\hline $\mathrm{mg} / \mathrm{dL}$ & $\mathrm{B}_{1}$ & $134.53 \pm 1.98$ & $127.18 \pm 3.87$ & $122.54 \pm 2.97$ & $128.08 \pm 2.94^{\mathrm{b}}$ \\
\hline & $\mathrm{B}_{2}$ & $130.21 \pm 3.45$ & $121.47 \pm 2.76$ & $113.32 \pm 1.68$ & $121.67 \pm 2.63^{\mathrm{c}}$ \\
\hline & $\mathrm{B}_{3}$ & $135.36 \pm 2.65$ & $128.11+3.79$ & $119.76+1.22$ & $127.74 \pm 2.55^{\mathrm{b}}$ \\
\hline Means & & $133.13 \pm 2.65^{\mathrm{a}}$ & $128.92 \pm 2.98^{b}$ & $124.99 \pm 1.94^{\mathrm{c}}$ & \\
\hline
\end{tabular}

HDL

The statistical analysis reported significant $(p \leq 0.05)$ effect of the treatment and time intervals $(0,14$ and 28$)$ on the HDL concentrations of rats under study. The effect of MAE of black cumin on the HDL levels in rats are mentioned in Table 3. Comparing the results of $B_{0}(45.627+2.12 \mathrm{mg} / \mathrm{dL})$, there was an increase noted in the values of $\mathrm{B}_{1}(51.930 \pm 2.22 \mathrm{mg} / \mathrm{dL}), \mathrm{B}_{2}(52.367 \pm 1.88 \mathrm{mg} / \mathrm{dL})$ and $\mathrm{B}_{3}$
$(52.060+2.24 \mathrm{mg} / \mathrm{dL})$, respectively. Furthermore, the HDL content was elevated from $48.790 \pm 1.89 \mathrm{mg} / \mathrm{dL}$ (0 day), to $50.462 \pm 1.85 \mathrm{mg} / \mathrm{dL}\left(14^{\text {th }}\right.$ day) and to $52.235 \pm 2.59 \mathrm{mg} / \mathrm{dL}\left(28^{\text {th }}\right.$ day), respectively. The percentage increase noted for the treatment groups in comparison to the $\mathrm{B}_{\mathrm{o}}$ were $12.14,12.88$ and $12.36 \%$; highest increase displayed by $\mathrm{B}_{2}$ group.

Table 3 Effect of MAE of Nigella sativa (black cumin) on HDL levels in hypercholesterolemic rats

\begin{tabular}{|c|c|c|c|c|c|}
\hline \multirow{2}{*}{ Parameter } & \multirow{2}{*}{ Treatments } & \multicolumn{3}{|c|}{ Study intervals (days) } & \multirow[t]{2}{*}{ Means } \\
\hline & & 0 & 14 & 28 & \\
\hline \multirow{5}{*}{$\begin{array}{l}\text { HDL cholesterol } \\
\mathrm{mg} / \mathrm{dL}\end{array}$} & $\mathrm{N}_{\mathrm{o}}$ & $50.31+2.18$ & $49.98+2.06$ & $46.87 \pm 1.96$ & $49.05 \pm 2.07$ \\
\hline & $\mathrm{B}_{\mathrm{o}}$ & $48.21 \pm 1.98$ & $46.83 \pm 1.67$ & $41.84 \pm 2.71$ & $45.627 \pm 2.12^{\mathrm{b}}$ \\
\hline & $\mathrm{B}_{1}$ & $49.76 \pm 1.81$ & $51.91 \pm 2.09$ & $54.12 \pm 2.76$ & $51.930 \pm 2.22^{\mathrm{a}}$ \\
\hline & $\mathrm{B}_{2}$ & $47.65 \pm 0.82$ & $52.23 \pm 1.84$ & $57.22 \pm 2.98$ & $52.367 \pm 1.88^{\mathrm{a}}$ \\
\hline & $\mathrm{B}_{3}$ & $49.54 \underline{ \pm} 2.65$ & $50.88 \pm 1.58$ & $55.76 \pm 2.54$ & $52.060 \pm 2.24^{\mathrm{a}}$ \\
\hline Means & & $48.790 \pm 1.89^{\mathrm{b}}$ & $50.462+1.85^{\mathrm{ab}}$ & $52.235 \pm 2.59^{\mathrm{a}}$ & \\
\hline
\end{tabular}

$\mathrm{N}_{\mathrm{o}}=$ Basal diet; $\mathrm{B}_{0}=\mathrm{HCD} ; \mathrm{B}_{1}=\mathrm{HCD}+\mathrm{MABCE}(150 \mathrm{mg} / \mathrm{kg} \mathrm{B} . \mathrm{W}.) ; \mathrm{B}_{2}=\mathrm{HCD}+\mathrm{MABCE}(300 \mathrm{mg} / \mathrm{kg} \mathrm{B} . \mathrm{W}.) ; \mathrm{B}_{3}=\mathrm{HCD}+\mathrm{MABCE}(450 \mathrm{mg} / \mathrm{kg} \mathrm{B} . \mathrm{W}$. $\mathrm{HCD}=$ High Cholesterol Diet

$\mathrm{MABCE}=$ Microwave Assisted Black Cumin Extract 


\section{Catalase (CAT)}

A significant $(p \leq 0.05)$ effect of treatment $(150,300 \& 450 \mathrm{mg} / \mathrm{kg} \mathrm{B} . \mathrm{W})$ and time intervals $(0,14 \& 28)$ on the levels of catalase enzyme was reported by the statistical analysis carried out. The effect of MABCEs on catalase levels of experimental hypercholesterolemic rats are presented in figure 3 . The maximum percent elevation was noted in group $\mathrm{B}_{2}(25.7 \%)$, followed by $\mathrm{B}_{3}(20.69 \%)$ and $\mathrm{B}_{1}(19.67 \%)$. However, in comparison to the control group $\mathrm{B}_{\mathrm{o}}(11.8 \pm 0.33 \mathrm{IU} / \mathrm{L})$ the levels of catalase observed in hypercholesterolemic experimental groups were $14.69 \pm 0.83 \mathrm{IU} / \mathrm{L} \quad\left(\mathrm{B}_{1}\right), \quad 15.89 \pm 0.87 \mathrm{IU} / \mathrm{L} \quad\left(\mathrm{B}_{2}\right)$ and $14.88 \pm 0.84 \mathrm{IU} / \mathrm{L} \quad\left(\mathrm{B}_{3}\right)$ respectively on $28^{\text {th }}$ day administration of MABCE. The highest elevation was observed for group $\mathrm{B}_{2}$.

\section{catalase}

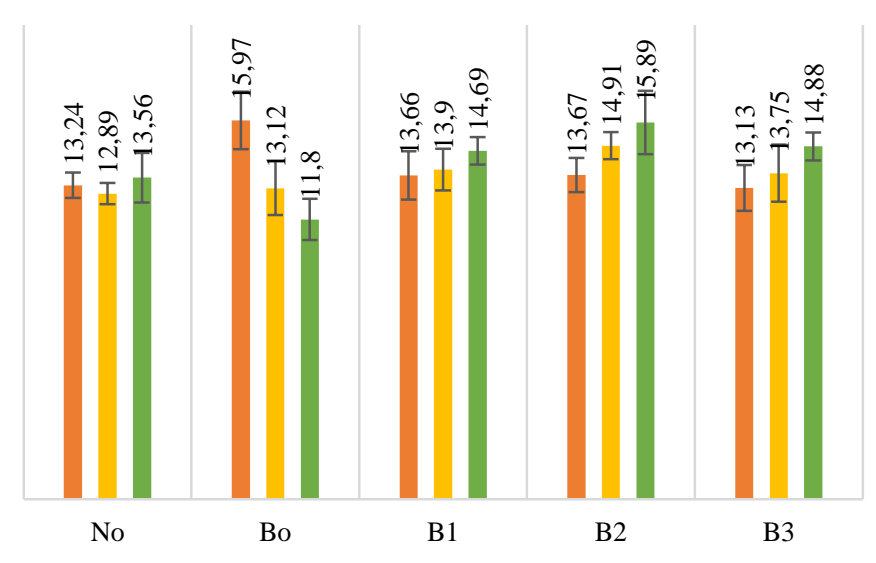

Figure 3 Effect of MAE of Nigella sativa (black cumin) of catalase (CAT) levels in hypercholesterolemic rats

$\mathrm{N}_{0}=$ Basal diet; $\mathrm{B}_{0}=\mathrm{HCD} ; \mathrm{B}_{1}=\mathrm{HCD}+\operatorname{MABCE}(150 \mathrm{mg} / \mathrm{kg} \mathrm{B} . \mathrm{W}.) ; \mathrm{B}_{2}=\mathrm{HCD}+$ MABCE (300mg/kg B.W.); B $_{3}=$ HCD + MABCE (450mg/kg B.W.)

\section{Superoxide Dismutase (SOD)}

The statistical analysis displayed a significant $(p<0.05)$ effect of the variables (time intervals and treatment) on the superoxide dismutase enzyme levels in the hypercholesterolemic experimental rats. The results for the levels of SOD in rats are reported in table 4. The concentration of SOD increased from $12.932 \pm 1.38 \mathrm{IU} / \mathrm{L}$ on 0 day to $13.235 \pm 1.11 \mathrm{IU} / \mathrm{L}$ on $14^{\text {th }}$ day and $14.263 \pm 0.89 \mathrm{IU} / \mathrm{L}$ on $28^{\text {th }}$ day, respectively. Moreover, comparing the results of $B_{B}$ $(12.293 \pm 0.74 \mathrm{IU} / \mathrm{L})$ an increase was observed in $\mathrm{B}_{1}(13.493 \pm 0.98 \mathrm{IU} / \mathrm{L}) . \mathrm{B}_{2}$ $(15.050 \pm 1.13 \mathrm{IU} / \mathrm{L})$ and $\mathrm{B}_{3}(13.070 \pm 1.04 \mathrm{IU} / \mathrm{L})$, respectively. The percent elevation noted was $15.14 \%, 19.83 \%$ and $16.35 \%$, showing the highest in $\mathrm{B}_{2}$.

\section{DISCUSSION}

Cholesterol, a sterol that is synthesized in the animal tissues because of it structural importance in the plasma membrane in the tissues (Kanter et al., 2005). It being the major component in the cell system works as function for the production of a number of hormones, bile acids and vitamin D (Kaleem et al. 2006). Moreover, in a study carried out previously determined the effect of black cumin seed extract (containing thymoquinone) at a concentration of 10 $\mathrm{mg} / \mathrm{kg} /$ day for treating hyperlipidaemic experimental rats for a period of 5 days reduced the levels of cholesterol and triglycerides considerably (Bader, 2015; Aljabre et al., 2015). The results shown in the various groups of rats under study found that the hypercholesterolemic group gained the highest body weight which was due to the induction before experiment was carried out. The high cholesterol diet also increased the energy intake of the rats along with elevated fat storage in the body (Onyeike et al., 2012). The results of the current study were noted to be in accordance with the studies carried out earlier by Akbarzadeh et al., (2015) which also showed a positive association between different doses of black cumin extracts and the lowering of the body weight in the model rats. The reason behind this decrease in weight is the ability of the black seed extracts to help in decreasing the absorption of fat and other lipogenic enzymes with increased excretion of fat from body (Rains et al., 2011). A similar study reported feeding $800 \mathrm{~g} / \mathrm{kg}$ per day of black cumin oil orally to the rats for a period of 4 weeks displayed lowering of LDL and triglycerides with an increase in HDL (ElDakhakhny et al., 2000). Another study administrating petroleum ether extract of black cumin extract in an oral dose of $1 \mathrm{ml} / \mathrm{kg}$ body weight of rats showed reduction of triglycerides (Al-Naqeep et al., 2011). The increase of triglycerides can be due to the reason of elevated expression of enzyme named acetyl CoA carboxylase along with fatty acid synthase that synthesizes triglycerides (Sukla $\boldsymbol{e}$ al., 2004). HDL is found to be involved in the transfer of cholesterol throughout the body assisting in reduction of accumulated cholesterol. It also prevented the deposition of LDL in the body (Elnaga et al., 2016). In a study earlier different formulations of black seed in form of oil, powder and methanolic extract in concentrations of $20-800 \mathrm{mg} /$ day, $100 \mathrm{mg}-20 \mathrm{~g} /$ day and $3.5-20 \mathrm{mg} /$ day, respectively recorded lowered level of LDL cholesterol (Srinivasan, 2018).

The extract of black cumin seed displayed protective effect against the damage that may occur to kidney tissues based on total antioxidant capacity, oxidative stress and levels of superoxide dismutase and CAT (catalase) (Yildiz $\boldsymbol{e t}$ al. 2010). A study showed that the concentration of $0.2 \mathrm{ml} / \mathrm{kg} /$ day helps in lowering the harmful effects on liver which promoted the elevation of antioxidant enzymes such as SOD, CAT, TAC which were used to examine the antioxidant status in rats with liver injury (Demir et al., 2006; Yildiz et al., 2008). A study by Sultan et al., (2015) indicated the effect of diet on the antioxidant enzymes such as SOD and CAT. The results confirmed that the use of black cumin in diet increased the levels of antioxidant enzymes which provide the safety parameter for the liver and kidney tissues.

Hypercholesterolemia is one of the factors that contribute towards a number of complications that lead to heart diseases, diabetes, obesity etc. The unhealthy lifestyles and diet related habits presents with evidence of such disorders prevailing worldwide. The need of the hour is to cope up with the disastrous health conditions and to develop a way in order to treat these diseases through natural remedies. Foods providing with beneficial phytochemicals are very important as they combat the oxidative stress inside the body by their antioxidant properties. Nutraceutical and functional foods being an important and very recent field of study has achieved a lot of appreciation. Naturally providing with the therapeutic agents in the form of nutraceuticals is the main goal. This also makes it possible to tackle a number of diseases by these nutraceuticals available by nature. The current study addresses the issue of hypercholesterolemia which has been treated with the black cumin seed extract due to its therapeutic potentials.

Table 4 Effect of MAE of Nigella sativa (black cumin) on SOD levels in hypercholesterolemic rats

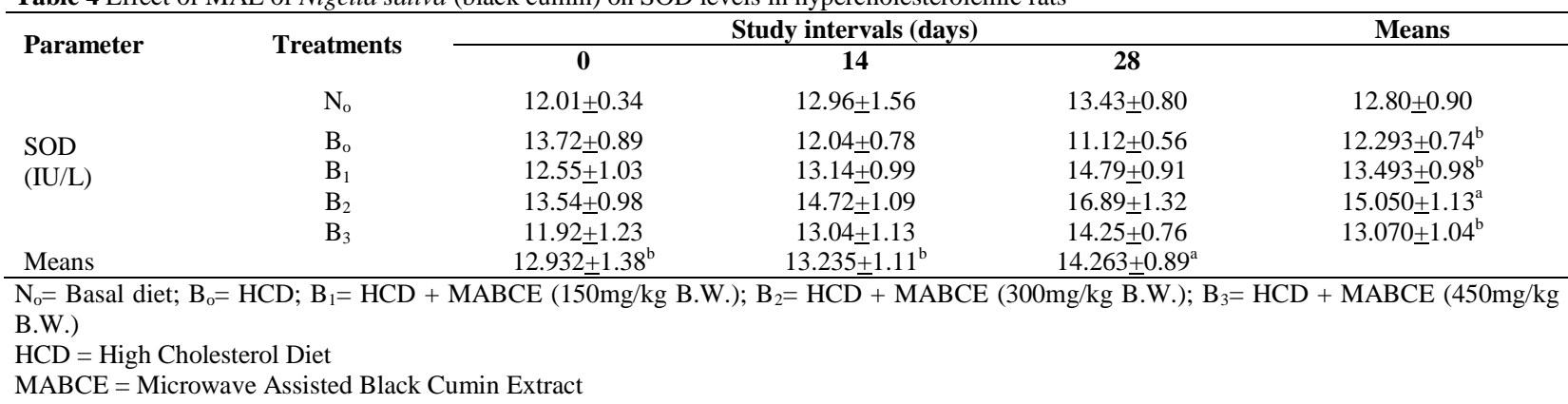

\section{CONCLUSION}

The black cumin seed also termed as Nigella sativa has a unique nutritional composition and is full of various phytochemicals thus being used as a functional food. In our current study we evaluated the microwave assisted extraction (MAE) of black cumin seed to obtain an extract that is rich is antioxidants along with other therapeutic properties. The extraction was carried out at optimum power and time to get the best yield, higher efficacy and lower use of solvent. The extract that displayed a great polyphenolic profile was used further to treat hypercholesterolemic albino rats for a period of 28 days after induction. The administration of the extracts showed a positive outcome and was able to reduce the levels of cholesterol, triglyceride and LDL along with an increase of HDL. The study proved that the black seed can be an important source of phytochemicals which provides treatment of hypercholesterolemia in humans as well because of the close similarity between the genome of humans and rats These seeds can easily be used in the daily diet and also provide its health benefits. 
Acknowledgment: The authors would like to acknowledge University Institute of Diet and Nutritional Sciences, The University of Lahore for their cooperation.

\section{REFERENCES}

Aggarwal, B. B., \& Kunnumakkara, A. B. (2009). Molecular targets and therapeutic uses of spices: modern uses for ancient medicine. World Scientific.

Akbarzadeh, S., Eskandari, F., Tangestani, H., Bagherinejad, S. T., Bargahi, A. Bazzi, P., ... \& Rahbar, A. R. (2015). The effect of Stevia rebaudiana on serum omentin and visfatin level in STZ-induced diabetic rats. Journal of dietary supplements, 12(1), 11-22. https://doi.org/10.3109/19390211.2014.901999

Aljabre, S. H., Alakloby, O. M., \& Randhawa, M. A. (2015). Dermatological effects of Nigella sativa. Journal of dermatology \& dermatologic surgery, 19(2), 92-98. https://doi.org/10.1016/j.jdds.2015.04.002

Al-Naqeep, G., Al-Zubairi, A. S., Ismail, M., Amom, Z. H., \& Esa, N. M. (2011) Antiatherogenic potential of Nigella sativa seeds and oil in diet-induced hypercholesterolemia in rabbits. Evidence-Based Complementary and Alternative Medicine, 2011. https://doi.org/10.1093/ecam/neq071

Bader, A.A., (2015). Anti-ischemic Properties of Nigella Sativa Against Cardiac and Non-Cardiovascular Ischemia. International Journal of Pharmacology Toxicology, 5(1): 53-61

Bamosa, A., Ali, B. A., \& Al-Hawsawi, Z. A. (2002). The effect of thymoquinone on blood lipids in rats. Indian Journal of Physiology and Pharmacology, 46(2), 195-201.

Bech-Larsen, T., \& Scholderer, J. (2007). Functional foods in Europe: consume research, market experiences and regulatory aspects. Trends in Food Science \& Technology, 18(4), 231-234. https://doi.org/10.1016/j.tifs.2006.12.006

Cheikh-Rouhou, S., Besbes, S., Hentati, B., Blecker, C., Deroanne, C., \& Attia, H. (2007). Nigella sativa L.: Chemical composition and physicochemica characteristics of lipid fraction. Food Chemistry, 101(2), 673-681. https://doi.org/10.1016/j.foodchem.2006.02.022

Demir, H., Kanter, M., Coskun, O., Uz, Y. H., Koc, A., \& Yildiz, A. (2006) Effect of black cumin (Nigella sativa) on heart rate, some hematological values, and pancreatic $\beta$-cell damage in cadmium-treated rats. Biological Trace Elemen Research, 110(2), 151-162. https://doi.org/10.1385/BTER:110:2:151

El-Dakhakhny, M., Mady, N. I., \& Halim, M. A. (2000). Nigella sativa L. oil protects against induced hepatotoxicity and improves serum lipid profile in rats. Arzneimittelforschung, 50(09), 832-836. https://doi.org/10.1055/s-00311300297

Elnaga, N. A., Massoud, M. I., Yousef, M. I., \& Mohamed, H. H. (2016). Effect of stevia sweetener consumption as non-caloric sweetening on body weight gain and biochemical's parameters in overweight female rats. Annals of Agricultural Sciences, 61(1), 155-163. https://doi.org/10.1016/j.aoas.2015.11.008

Espín, J. C., García-Conesa, M. T., \& Tomás-Barberán, F. A. (2007) Nutraceuticals: facts and fiction. Phytochemistry, 68(22-24), 2986--3008. https://doi.org/10.1016/j.phytochem.2007.09.014

Imran, A., Butt, M. S., Arshad, M. S., Arshad, M. U., Saeed, F., Sohaib, M., \& Munir, R. (2018). Exploring the potential of black tea-based flavonoids against hyperlipidemia related disorders. Lipids in Health and Disease, 17(1), 57. https://doi.org/10.1186/s12944-018-0688-6

Kaleem, M., Kirmani, D., Asif, M., Ahmed, Q., \& Bano, B. (2006). Biochemica effects of Nigella sativa $L$ seeds in diabetic rats.

Kanter, M., Demir, H., Karakaya, C., \& Ozbek, H. (2005). Gastroprotective activity of Nigella sativa L oil and its constituent, thymoquinone against acute alcohol-induced gastric mucosal injury in rats. World Journal of Gastroenterology: $\quad$ WJG, 11(42), 6662. https://dx.doi.org/10.3748\%2Fwjg.v11.i42.6662

Khalid, A., Bashir, S., Khalil, A. A., Khan, A. A., Khan, M. A., Gull, H., ... \& Batool, A. (2019). Varietal comparison of proximate analysis and mineral composition of black cumin seed powder. Pakistan Journal of Food Sciences, 29(2), 5-9.

Khazdair, M. R. (2015). The protective effects of Nigella sativa and its constituents on induced neurotoxicity. Journal of toxicology, 2015. https://doi.org/10.1155/2015/841823

Liu, X., Park, J. H., Abd El-Aty, A. M., Assayed, M. E., Shimoda, M., \& Shim, J. H. (2013). Isolation of volatiles from Nigella sativa seeds using microwaveassisted extraction: effect of whole extracts on canine and murine CYP1A. Biomedical Chromatography, 27(7), 938-945 https://doi.org/10.1002/bmc.2887

Makni, M., Fetoui, H., Gargouri, N. K., Garoui, E. M., Jaber, H., Makni, J., \& Zeghal, N. (2008). Hypolipidemic and hepatoprotective effects of flax and pumpkin seed mixture rich in $\omega-3$ and $\omega-6$ fatty acids in hypercholesterolemic rats. Food and Chemical Toxicology, 46(12), 3714-3720. https://doi.org/10.1016/j.fct.2008.09.057

Onyeike, E. N., Monanu, M. O., \& Okoye, C. N. (2012). Changes in the blood lipid profile of wistar albino rats fed rich cholesterol diet.

Rains, T. M., Agarwal, S., \& Maki, K. C. (2011). Anti-obesity effects of green tea catechins: a mechanistic review. The Journal of Nutritional Biochemistry, 22(1), 1-7. https://doi.org/10.1016/j.jnutbio.2010.06.006
Ramadan, M. F., \& Mörsel, J. T. (2003). Analysis of glycolipids from black cumin (Nigella sativa L.), coriander (Coriandrum sativum L.) and niger (Guizotia abyssinica Cass.) oilseeds. Food Chemistry, 80(2), 197-204. https://doi.org/10.1016/S0308-8146(02)00254-6

Shukla, R., Gupta, S., Gambhir, J. K., Prabhu, K. M., \& Murthy, P. S. (2004). Antioxidant effect of aqueous extract of the bark of Ficus bengalensis in hypercholesterolaemic rabbits. Journal of Ethnopharmacology, 92(1), 47-51. https://doi.org/10.1016/j.jep.2004.01.020

Srinivasan, K. (2018). Cumin (Cuminum cyminum) and black cumin (Nigella sativa) seeds: traditional uses, chemical constituents, and nutraceutical effects. Food Quality and Safety, 2(1), 1-16. https://doi.org/10.1093/fqsafe/fyx031

Steel, R. G. (1997). Pinciples and procedures of statistics a biometrical approach (No. $519.5 \mathrm{~S} 8$ ).

Sultan, M. T., Butt, M. S., Karim, R., Ahmed, W., Kaka, U., Ahmad, S., \& ZiaUl-Haq, M. (2015). Nigella sativa fixed and essential oil modulates glutathione redox enzymes in potassium bromate induced oxidative stress. BMC Complementary and Alternative Medicine, 15(1), 330 https://doi.org/10.1186/s12906-015-0853-7

World Health Organization. (2019). Global action plan on physical activity 2018 2030: more active people for a healthier world. World Health Organization.

Yildiz, F., Coban, S., Terzi, A., Ates, M., Aksoy, N., Cakir, H., \& Bitiren, M. (2008). Nigella sativa relieves the deleterious effects of ischemia reperfusion injury on liver. World Journal of Gastroenterology: WJG, 14(33), 5204 https://dx.doi.org/10.3748\%2Fwig.14.5204

Yildiz, F., Coban, S., Terzi, A., Savas, M., Bitiren, M., Celik, H., \& Aksoy, N (2010). Protective effects of Nigella sativa against ischemia-reperfusion injury of kidneys. Renal Failure, 32(1) 126-131. 